\title{
GENETIC ANALYSIS OF VARIETAL DIFFERENTIATION IN CEREALS*
}

\author{
IV. POLYGENIC DIFFERENCES IN AGRONOMIC CHARACTERS \\ BETWEEN LOCAL STRAINS OF A BARLEY VARIETY, "HAKATA NO. 2"
}

\author{
Kanji Goтон \\ National Institute of Genetics, Misima, Japan
}

Received December 19, 1955

UDC 575. $11: 582.542 .1: 633.16$

A highly-bred variety of autogamous plants released from breeders with a high level of homozygosity may maintain its characteristics generation after generation, although the range of its distribution is increasing from year to year. Kanda et al. (1952) observed that it was difficult to distinguish statistically two ecological types of the rice variety "Rikuu No. 132 ", which were grown under markedly different local conditions during more than 10 years. According to Simpson and Duncan (1953), no important genetic changes occurred in 5 cotton varieties (partially cross-pollinated plant) during 5 generations of seed multiplication, and they concluded that well-bred varieties of cotton will maintain their botanical purity during a considerable long period of multiplication. Polygenic segregation during the period of multiplication may be of minor importance from the practical view point. However, how natural selection affects the polygenic characters of cultivated varieties may be of interest in connection with population genetics. In order to obtain some information on this point and to throw some light on the effect of natural selection upon a cross-bred variety, five local strains of such a variety of beer barley were examined in a comparative experiment.

\section{Materials and Methods}

"Hakata No. 2" is an old 2-rowed variety of beer barley, which was released from the Breeding Station of Hakata Manufactory of Nihon Brewery Lid. in 1925. It is a selection from a cross between Australian Chevallier $\times$ Goldthorpe.

5 seed samples of this variety were examined. Letters $A, B, C, D$ and $E$ stand for the names of the seed samples.

$A$ Obtained from Hokkaido Nat. Agr. Exp. Sta., Sapporo, Hokkaido.

$B$ From Hokuriku Nat. Agr. Exp. Sta., Takata, Niigata Prefecture.

$C$ From Kantô-Tôzan Nat. Agr. Exp. Sta., Kônosu, Saitama Prefecture.

$D$ From Tôkai-Kinki Nat. Agr. Exp. Sta., Tsu, Mie Prefecture.

E From Kyûshû Nat. Agr. Exp. Sta., Tikugo, Fukuoka Prefecture.

* Contributions from the National Institute of Genetics, Japan, No. 142. 
$B$ strain has been kept until 1950 at the Suita Manufactory of Kirin Brewery Ltd. thereupon it was sent to Hokuriku Nat. Agr. Exp. Sta.. Therefore, the period of multiplication of this strain at Takata was short. However, the other strains were grown in each location during a period of more than 12 years.

A comparative study of these strains was conducted in 1953 and 1954 on the experimental fields of the Nat. Inst. Genet., Misima. The plants were grown $10 \mathrm{~cm}$ apart in rows spaced $50 \mathrm{~cm}$ apart in a randomized block arrangement with 5 replications. 15 plants were selected at random from each plot, and culm length, ear length, number of spikelets on one side and number of ears per plant were determined on individual basis, and grain yield and weight of 1000 grains on plot basis.

\section{Experimental results}

Upon visual inspection, the botanical features of all five strains were similar. Differences found among them were of statistical nature. In Table 1, the average means of 2 years for three characters are represented. The differences in these characters between the strains were very slight and statistically non-significant.

Table 1 Comparison between the local strains $A \sim E$ (averge of two years)

\begin{tabular}{c|c|c|c} 
Strains & $\begin{array}{c}\text { Grain yield } \\
\text { per plant (g) }\end{array}$ & $\begin{array}{c}\text { Number of } \\
\text { ears per plant }\end{array}$ & $\begin{array}{c}\text { Date of } \\
\text { heading* }\end{array}$ \\
$A$ & 15.4 & 15.2 & April 20.9 \\
$B$ & 14.6 & 16.5 & 21.2 \\
$C$ & 13.3 & 16.2 & 21.2 \\
$D$ & 16.0 & 17.2 & 20.5 \\
$E$ & 14.6 & 15.5 & 20.7
\end{tabular}

* Observed on plot basis.
Table 2 shows the means of 4 characters, namely, culm length, ear length, number of spikelets on one side of ear and weight of 1000 grains. The results of variance analysis are represented in Table 3. The differences in these characters between the local strains were statistically signifi-

Table 2 Results of comparative experiments with the local strains $A \sim E$ in 1953 and in 1954

\begin{tabular}{cccccccccc} 
& \multicolumn{2}{c}{$\begin{array}{c}\text { Culm length }(\mathrm{cm}) \\
\text { Strains }\end{array}$} & \multicolumn{2}{c}{ Ear length $(\mathrm{cm})$} & Number of spikelets & \multicolumn{2}{c}{$\begin{array}{c}\text { Weight of } 1000 \\
\text { grains }\end{array}$} \\
& 1953 & 1954 & 1953 & 1954 & 1953 & 1954 & 1953 & 1954 \\
\hline$A$ & 101.8 & 77.2 & 7.69 & 7.40 & 15.8 & 14.9 & 42.2 & 43.1 \\
$B$ & 103.0 & 81.8 & 7.98 & 7.73 & 16.3 & 15.6 & 40.4 & 44.6 \\
$C$ & 100.6 & 79.6 & 7.94 & 7.82 & 16.1 & 15.6 & 41.9 & 45.2 \\
$D$ & 105.2 & 78.4 & 8.30 & 8.21 & 16.6 & 15.8 & 45.0 & 46.4 \\
$E$ & 104.6 & 82.0 & 8.20 & 7.93 & 16.7 & 15.8 & 42.1 & 44.9
\end{tabular}

cant at the 1 and .5 per cent level, and variances due to years were highly significant. As seen from Table 2, the ears were shorter and the number of spikelets was smaller in $A, B$ and $C$ than in $D$ and $E$. The former 3 strains were obtained from northern locations and the latter 2 from the southern ones. In general, one could find in both characters a clinal variation among the strains. The differences between $D$ and $E$ in ear length may be explained as due to the short period of its multiplication at the 
Table 3 Analysis of variance

\begin{tabular}{|c|c|c|c|c|c|}
\hline \multirow{2}{*}{ Factors } & \multirow{2}{*}{ d. $f$. } & \multicolumn{4}{|c|}{ m. s. } \\
\hline & & Culm length & Ear length & $\begin{array}{l}\text { Number of } \\
\text { spikelets }\end{array}$ & Weight of 1000 grains \\
\hline Year (Y) & 1 & $6751^{* *}$ & $0.5121^{* *}$ & $7.22^{* *}$ & $79.38^{* *}$ \\
\hline Strains (S) & 4 & $25^{*}$ & $0.7034^{* *}$ & $1.36^{* *}$ & $15.70^{* *}$ \\
\hline Blocks（B) & 4 & $23^{*}$ & $0.0669^{*}$ & 0.29 & $8.81^{* *}$ \\
\hline $\mathrm{Y} \times \mathrm{S}$ & 4 & 15 & 0.0194 & 0.0025 & $4.89^{*}$ \\
\hline $\mathrm{Y} \times \mathrm{B}$ & 4 & 17 & $0.0582^{*}$ & 0.20 & $11.52^{* *}$ \\
\hline $\mathrm{S} \times \mathrm{B}$ & 16 & 9 & 0.0331 & 0.14 & 1.97 \\
\hline $\mathrm{Y} \times \mathrm{S} \times \mathrm{B}$ & 16 & 6.3 & 0.0191 & 0.13 . & 1.60 \\
\hline
\end{tabular}

northern location, as previously mentioned. In Table 4, the frequency distribution of ear length is represented for 1953.

Table 4 Frequency distribution of ear length in 1953

\begin{tabular}{c|ccccccccc|c}
\hline Strains & 6.5 & 6.9 & 7.3 & 7.7 & 8.1 & 8.5 & 8.9 & 9.3 & 9.7 & Total \\
\hline$A$ & - & 10 & 23 & 19 & 19 & 3 & 1 & - & - & 75 \\
$B$ & 1 & 5 & 8 & 15 & 23 & 16 & 6 & 1 & - & $" 1$ \\
$C$ & - & 2 & 14 & 20 & 18 & 18 & 3 & - & - & $" 1$ \\
$D$ & 1 & 1 & 5 & 8 & 16 & 26 & 12 & 5 & 1 & $" 1$ \\
$E$ & - & 1 & 6 & 14 & 24 & 21 & 6 & - & 3 & $" 1$ \\
\hline
\end{tabular}

The differences between the strains in the examined characters were generally small. In order to find out if such differences are governed by polygenes, it would be necessary to analyze the hybrid populations between the strains having long and short ears and so forth. But in cases, where the interactions between years and strains were non-significant, the explanation of differences between local strains by polygenes seems to be plausible.

\section{Discussion}

In cross-bred varieties even of autogamous plants more or less segregations regarding quantitative and undetectable characters take place after releasing. If there are differences between segregants in their reproductive ability in respect to the lacal conditions where the varieties are grown, there will occur a varietal differentiation during the period of multiplication, as also pointed out by Nijdam (1954).

The effect and role of natural selection upon cultivated plants have been. explored by many workers. In wild and cultivated strains of Trifolium repens, Daday (1954, a, b. c) found a gene frequency cline which was associated with the isotherm of January.

According to the results of my experiments, statistical differences were found between local strains in several agronomic characters; it is assumed that these dif- 
ferences may be due to polygenes.

Hagberg et al. (1952) found that number of loci and polygenes governing ear density exceeds by our speculation. Such a situation probably exists also in respect to other ear characters, i. e. ear length and number of spikelets, which were dealt with in my experiments. Although the number of strains examined was too small to make this hypothesis valid, a clinal variation in ear length and number of spikelets was noticeble. The results of comparative experiments indicate that the original population of "Hakata No. 2" might have been heterozygous regarding ear characters and after releasing polygenic segregations has taken place. It is assumed that the variation found in those characters was due to natural selection through influence of different local conditions.

\section{Summary}

5 seed samples of 2-rowed beer barley " Hakata No. 2 " were obtained from widely separated locations, ranging from Hokkaido to Kyûshû, and compared with each other in a randomized block arrangement with 5 replications during two years.

The differences found among them were of statistical nature, and upon visual inspection, they were undiscernible. Differences between local stratins in grain yield, number of ears per plant and date of heading were non-significant, whereas those in culm length, ear length, number of spikelets and weight of 1000 grains were significant.

It is assumed that these differences may be governed by polygenes. As seen from Table 2 and 4, a clinal variation was found in ear length and number of spikelets. These variations were explained as being the result of polygenic segregations under the pressure of natural selection according to the local conditions.

\section{Literature cited}

Daday, H. 1954 a. Gene frequencies in wild populations of Trifolium repens. I. Distribution by latitude. Hereeity 8 (1) : 61-78.

Daday, H. 1954 b. Gene frequencies in wild populations of Trifolium repens. II. Distribution by artitude. Heredity $8(3): 377: 84$.

Daday, H. 1954 c. Gene frequencies in strains of Trifolium repens L. Nature $174: 521$.

Hagberg, A., N. Nybom, and Å. Gustafsson 1952. Allelism of erectoides mutation in barley. Hereditas $38: 510-2$.

Kanda, M., M. Okada, and C. Hori 1952. Genecological studies on the rice variety' "Rikuu No. 132 ". Jap. Jour. Breed. 1 (3) : 161-6. (Japaese with English summary)

Nijdam F. E. 1954. The variety in its diversity. Euphytica 3 (3) : 181-240.

Simpson D. M., and E. N. Duncan 1953. Stability of cotton varieties. Agr. Jour. 45(9) : 448-50. 